\title{
Assessing the User Experience of E-Books in Academic Libraries
}

\section{Tao Zhang, Xi Niu, and Marlen Promann*}

\begin{abstract}
We report findings from an assessment of e-book user experience (search and information seeking) from usage data and user tests. The usage data showed that most reading sessions were brief and focused on certain pages, suggesting that users mainly use e-books to find specific information. The user tests found that participants tended to use default keyword search and browse the search results. Experience levels with e-books and features of e-book platforms influenced users' information seeking in e-books. The assessment results have significant implications for designing e-book features to support users' reading strategies and help libraries create a consistent user experience.
\end{abstract}

\section{Introduction}

E-books are being widely adopted in academic libraries as a new format for scholarly resources, largely for their apparent advantages over print books (such as storage and cost). The literature on e-books has covered an array of themes, including library adoption of e-books, acquisition models, the supply side of e-book market, promotion among users, cataloging, copyright, and digital rights management (DRM). ${ }^{1}$ These themes are useful in determining library acquisition strategies and designing e-book-related services; however, the role of e-books in users' information-seeking processes remains comparatively unexplored.

While a number of studies have reported faculty's and students' perceptions and attitudes of e-books, ${ }^{2}$ less is known on user actual behavior with and around e-books. ${ }^{3}$ A few usability studies have examined specific e-book platforms ${ }^{4}$ but there is still the need for libraries to better understand the discovery and actual use of e-books. Understanding these phases holistically as users' information-seeking behavior can facilitate a user-centered approach to improving e-books, as well as their use and adoption in academic libraries.

The goal of this study was to better understand the discovery and use of e-books in an academic library. To this end, we developed a new assessment methodology by integrating e-book usage data and behavior observation in user tests. We expected the usage data to show patterns of user interaction with e-books, which should serve as the basis for designing user test tasks. In the user tests, we observed how participants

*Tao Zhang is Digital User Experience Specialist at Purdue University; e-mail: zhangtao2000@gmail.com. $\mathrm{Xi}$ Niu is Assistant Professor of Software and Information Systems at University of North Carolina at Charlotte; e-mail:xniu2@uncc.edu. Marlen Promann is at Purdue University; e-mail: mpromann@purdue. edu. (O2017 Tao Zhang, Xi Niu, and Marlen Promann, Attribution-NonCommercial (http://creativecommons.org/licenses/by-nc/4.0/) CC BY-NC. 
search, select, and read information from e-books. We expected our observations of participants' behavior to reveal how users perceive and interact with current e-book platforms and identify key usability issues that affect the reading experience. The findings could help libraries identify directions for improving users' experience and acceptance of e-books.

\section{Related Work}

\section{E-book Usability}

The general advantages of e-books over print books have been discussed from both the users' and libraries' perspectives (such as cost and storage requirement). ${ }^{5}$ Userperceived value of e-books differs largely from that of physical print books. Users regard e-books as a quick reference tool that is available $24 / 7 .{ }^{6}$ The majority prefer to use e-books to find relevant information via selective reading. ${ }^{7}$ Due to the nonsequential reading, with frequent flipping back and forth, Dana McKay suggested that e-books are used like journal articles, with clear in-document navigation points, such as title, abstract, and section headings. ${ }^{8}$

Search and navigation functions are critical to users' acceptance of e-books as scholarly resources, yet users struggle to navigate e-books effectively. ${ }^{9}$ Noorhidawati Abdullah and Forbes Gibb showed that back-of the-book index was more efficient (that is to say, it had a shorter task time) and accurate than table of contents or fulltext search, for finding information in an e-book. ${ }^{10}$ Other features of e-books, such as downloading, offline use, printing, text highlighting, annotating, and copying and pasting text, have also been repeatedly found important for users to develop positive attitude toward e-books. ${ }^{11}$

Offering e-books via third-party vendors' platforms poses challenges for libraries to provide a consistent e-book user experience. ${ }^{12}$ Different features on different platforms (such as printing, highlighting, and access restrictions) cause an inconsistent user experience, which hinders e-books discovery and usability. ${ }^{13}$ As a result, users' awareness of and access to e-books varies across different disciplines and institutions; ${ }^{14}$ however, a number of studies with students across disciplines have revealed how students do not clearly distinguish between resource types (such as online journals, conference proceedings, and e-books) and that they may be accessing e-books without knowing their exact resource type. ${ }^{15}$

Previous studies of users' attitudes, preferences, and use of e-books have not been interpreted and discussed in a user experience research framework. Studies that explore the human-document interaction are less common, but they are increasingly important for improving efficiency and comprehension of the information-seeking process. ${ }^{16}$ Furthermore, there are few guidelines for optimizing user experience and task performance with e-books in academic libraries.

\section{E-book User Experience}

User experience involves a person's perception, attitude, emotion, and interaction with a particular product, system, or service over time and across multiple touchpoints. As such, user experience of e-books should cover the entire interactive process: (1) perceiving e-books as a useful information resource; (2) discovering e-books from library collections; and (3) using e-books in different contexts (see figure 1).

Users' perceptions of e-books include their awareness of e-books as a resource, their attitude and preference of using e-books (or not). Awareness, attitude, and preference jointly affect users' intentions to use e-books, which translates into the discovery and actual use. In the discovery phase, users search for relevant e-book titles and identify the ones for further examination. The results of discovery may affect users' perception 


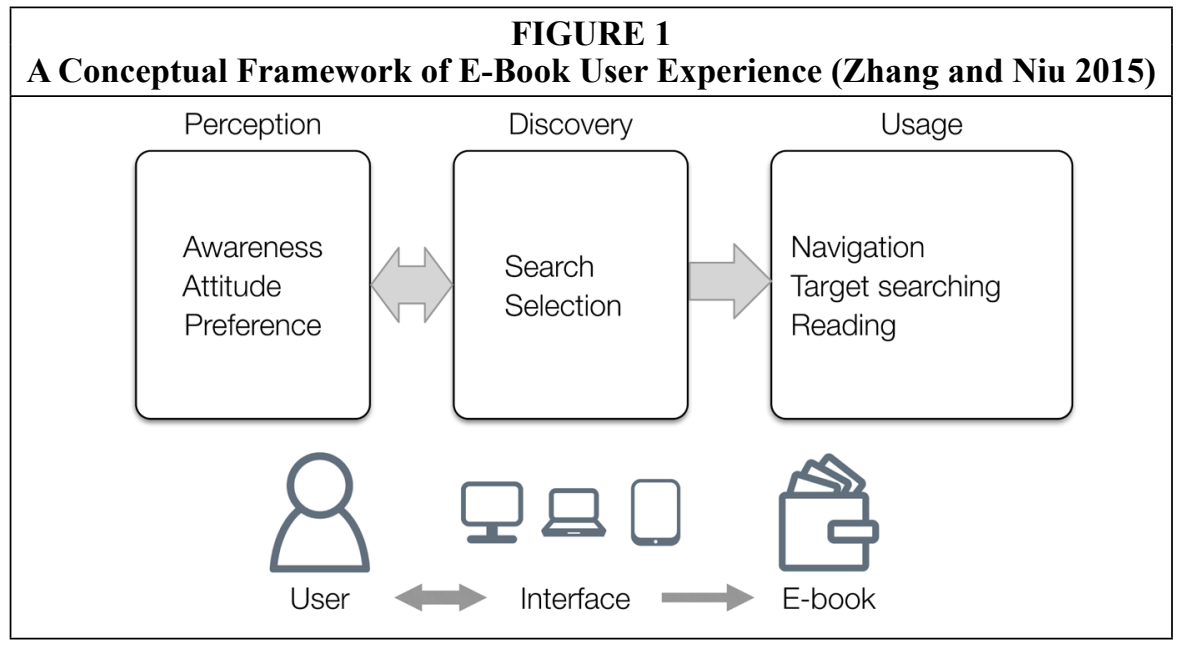

of e-books as a potential resource. The actual use of e-books involves navigating within the e-book content, seeking targeted information, and reading the content. Perception, discovery, and use of e-books are affected by users' interaction with the e-book interface and how the interface presents features and content to users. The assessment of these three phases from the perspective of a user interacting with e-books could be helpful in better understanding the determinants of a quality experience. ${ }^{17}$

As mentioned, previous studies have identified an issue of e-book awareness among users. ${ }^{18}$ Users' attitudes toward e-books depend on the perceived value and utility and, more important, the technical aspects of access to e-books (for example: downloading, printing, text highlighting, annotating, copying text, and so on). Users' preference of book format (e-books or print books) is influenced by the context of their information need as well as individual differences. Many users prefer print books for extended reading, while they generally use e-books for selective reading and fact finding. ${ }^{19}$

This study is focused on the discovery and usage phases of e-book user experience. Discovery and access pose as significant barriers to extensive e-book adoption in academic libraries, particularly because many users have difficulty identifying the e-books they need and understanding where to search and locate them. Academic e-books are usually used as online references to extract information for study and research, ${ }^{20}$ but ebook features and interface may affect the information retrieval performance. Previous studies on e-book reading (that is to say, human-document interaction) have revealed a nonlinear pattern caused by possible disconnection between users' experience of print and e-books. ${ }^{21}$ The disconnection is probably caused by the lack of support in e-book interface for effective navigation and information retrieval that is critical for nonlinear reading of scholarly publications. To address those issues, it is important to first apply a structured, user-centered assessment approach to better understand users' interaction with e-books in both the discovery and usage phases. This assessment approach should include analysis of usage data for typical interactions and user tests to further understand how current e-books support those interactions.

\section{E-Book Usage Analysis}

We collected an e-book usage report from EBL from January 1 to November 25, 2014, consisting of 29,495 individual reading sessions. Data fields for each session include date and time, duration, anonymized user ID, title of e-book accessed, book ID, publisher, category of the e-book, page numbers browsed by the user in a sequential list, 
total pages read by the user, and whether the e-book was downloaded. Our analysis of the data fields covered session duration, downloads, and pages browsed by users, as they directly show behavioral details of user interaction with e-books.

Table 1 shows the descriptive statistics of the session duration in seconds. In addition, 69 percent of the reading sessions lasted less than 10 minute, and 92 percent of all sessions lasted less than 30 minutes in (see figure 2). Although the session duration measure may not be accurate since users could keep the e-books open while working on other things, the distribution of data shows that most user interactions with e-books were very brief.

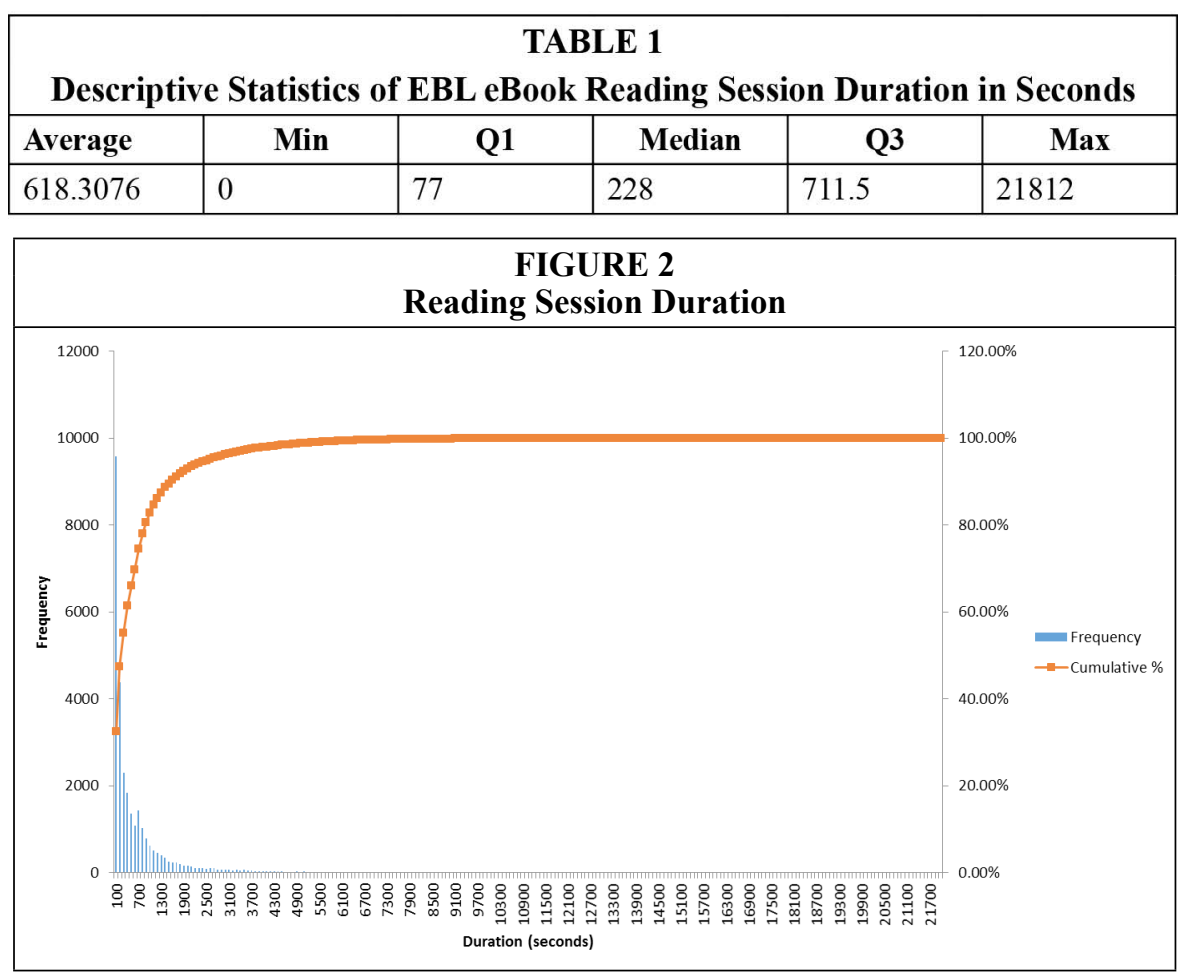

EBL has the option for users to download e-books if needed, and there could be multiple downloads in one user session. We define a session as a download session when there was at least one download action. There were 2,261 download sessions $(8 \%)$ among all user e-book reading sessions.

The EBL usage report shows the page numbers browsed by users during each session (for instance, " $1,2,3,4,10,11^{\prime \prime}$ ). The descriptive statistics of the page numbers browsed are shown in table 2 . The histogram and cumulative frequency distribution of the page numbers browsed are shown in figure 3. We found that 80 percent of all reading sessions involved no more than 30 pages browsed by users. Users tended to start the reading from the beginning of the e-book, but most of the readings covered relatively small number of pages.

TABLE 2

Descriptive Statistics of E-Book Page Numbers Browsed by Users

\begin{tabular}{|l|c|c|c|c|c|}
\hline Average & Min & Q1 & Median & Q3 & Max \\
\hline 22.56708 & 0 & 8 & 14 & 27 & 618 \\
\hline
\end{tabular}




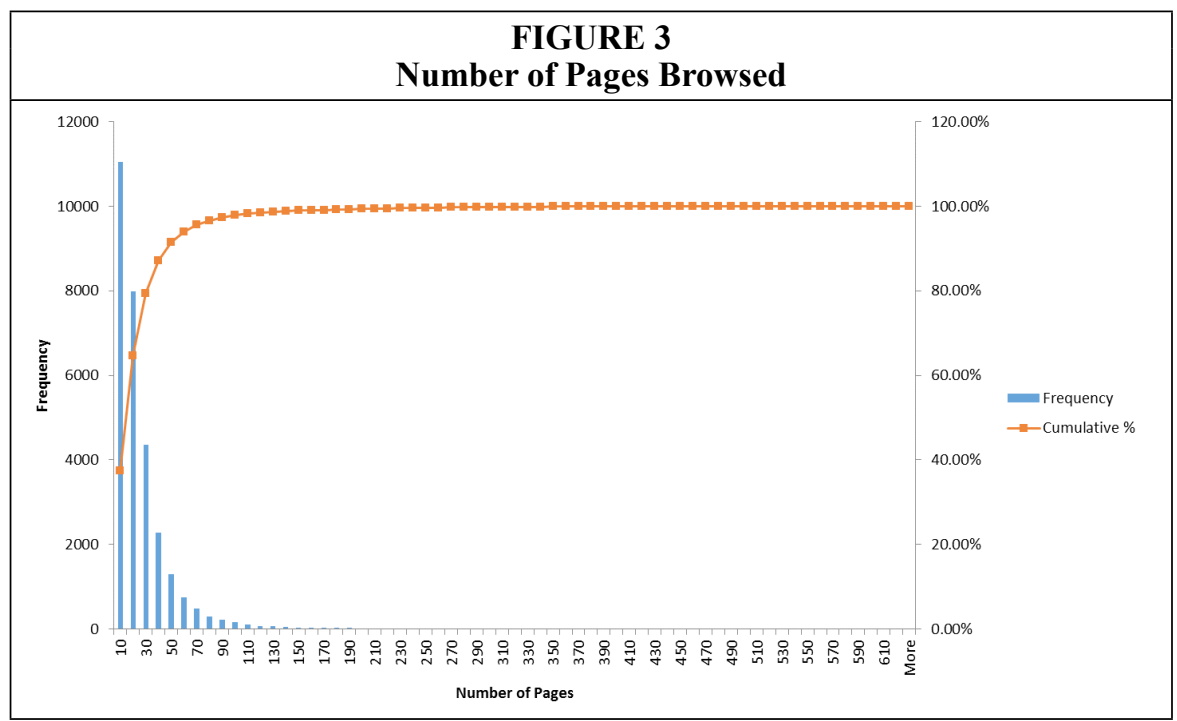

We developed an interactive visualization showing the number of user sessions for reading individual pages across all e-books and grouped by publishers (screenshot shown in figure 4). The visualization shows that users tended to browse the beginning of e-books, and there are higher number of sessions ("spikes") on other page ranges for certain e-books and publishers. Those "spikes" suggest that users selected a few pages or sections of some e-books to read, potentially based on their research or study needs.

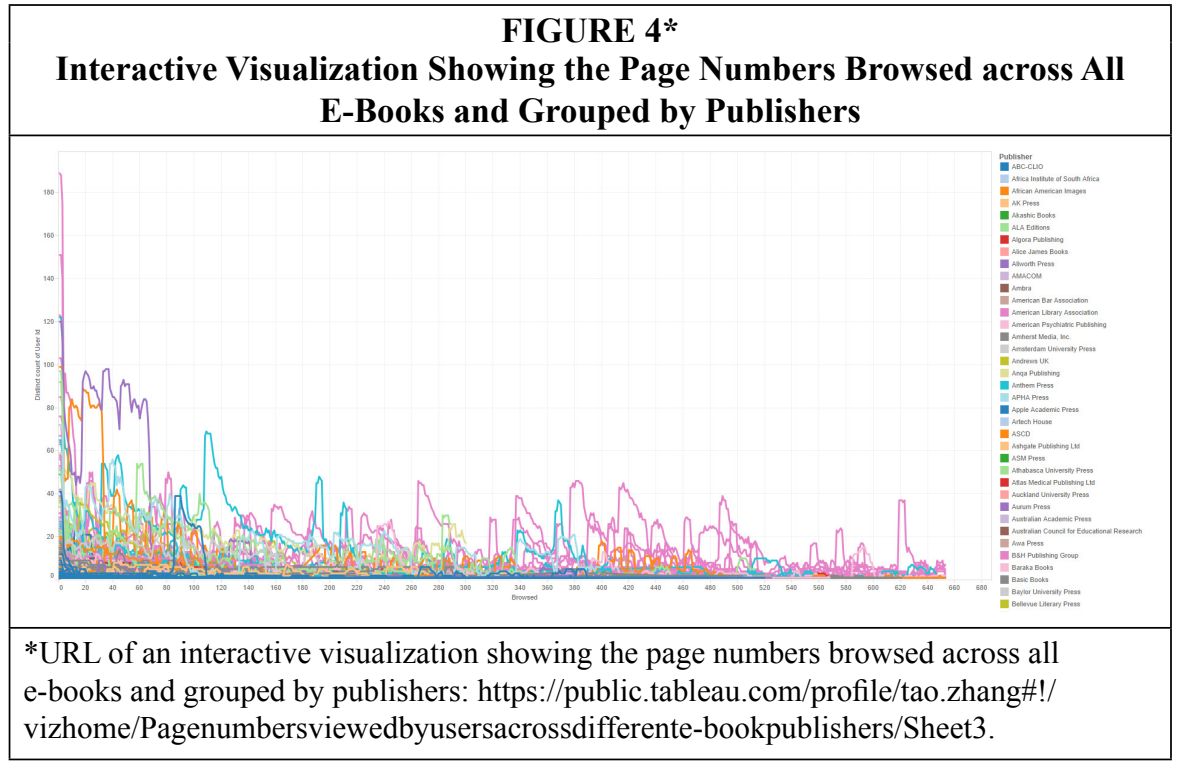

Another visualization of the number of sessions for reading individual pages across e-books and grouped by subject categories (screenshot shown in figure 5) shows a similar pattern. Most sessions cover beginnings of e-books, and there is higher usage of some page ranges for certain e-book categories. 


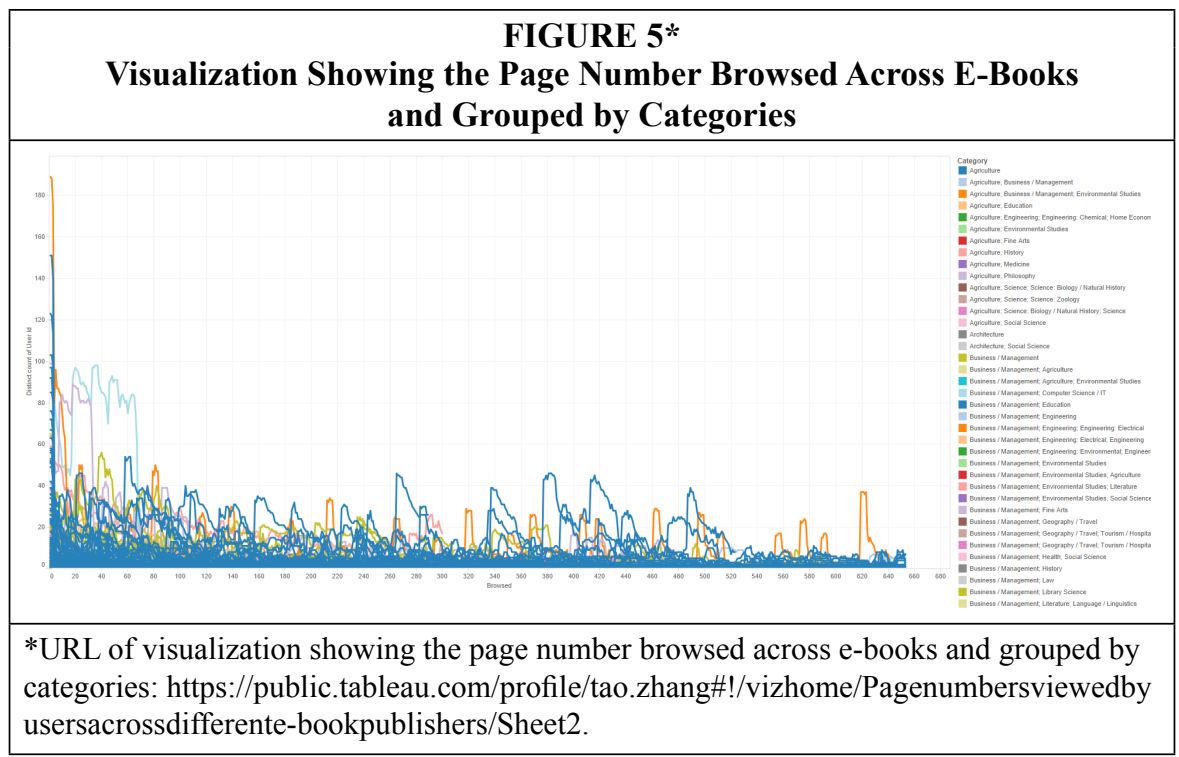

\section{User Test}

\section{Method}

We recruited 12 participants (two faculty members, three undergraduate students, two master students, and five doctoral students) at Purdue University for the user tests. There are three male and nine female participants, with an average age of 30.3 years and standard deviation of 9.7. An online screening questionnaire (see appendix A) was used to classify and select participants from three experience groups (four participants from each group): beginners, intermediate, and expert users. Specifically, question 1 of the screening questionnaire collected 7-point frequency scale of candidates' experiences with the library website; finding books and scholarly articles; reading, downloading, and printing e-books from library website; using e-book readers like Kindle; and reading e-books in mobile phone or tablet. For each response, we assigned numbers from 1 to 7 to the options from "Never" to "Daily," accordingly. The total 50 collected candidate responses were then summed and ranked. The 12 participants were randomly selected from the top 10, 20 to 30, and last 10 candidates, four from each group. All selected participants agreed and participated in the user test. Participants' experience grouping, current status, and discipline background are listed in table 3. Table 3 suggests that users' experience with library website and e-books increases with more research experience (that is, being a professor or doctoral student versus undergraduate student).

We included other questions in the screening questionnaire to cross-check the grouping results with candidates' behavior patterns. In general, we observed that, as candidates' self-reported experiences with the library and e-books increase, their use of e-books becomes more diversified (that is, more detailed answers to questions 2 and 3 , and more options selected for questions 4 and 5). Note that detailed analysis of responses to other questions of the screening questionnaire was not in the scope of this paper.

Participants performed two types of test tasks: searching for e-books on general topics and finding pieces of information in specific e-books (see table 4). The general search topics were randomly chosen from past keywords submitted to the library's discovery tool. We separated the searching tasks from information retrieval tasks, because pilot tests showed that it was difficult for participants to develop the correct search queries and locate the particular e-books required by the information retrieval 
TABLE 3

Participants' Experience Grouping, Current Status and Discipline Background

\begin{tabular}{|l|l|l|l}
\hline $\begin{array}{c}\text { Participant } \\
\#\end{array}$ & $\begin{array}{c}\text { Experience } \\
\text { Grouping }\end{array}$ & Current Status & \multicolumn{1}{|c}{ Discipline Background } \\
\hline 1 & Intermediate & Master student & Geology and Geophysics \\
\hline 2 & Intermediate & Doctoral student & Philosophy \\
\hline 3 & Intermediate & Doctoral student & $\begin{array}{l}\text { Aeronautics and Astronautics } \\
\text { Engineering }\end{array}$ \\
\hline 4 & Beginner & Master student & Industrial Engineering \\
\hline 5 & Experienced & Doctoral student & Electrical Engineering \\
\hline 6 & Beginner & Freshman & Economics \\
\hline 7 & Experienced & Professor & Theatre \\
\hline 8 & Experienced & Associate Professor & English \\
\hline 9 & Beginner & Senior & $\begin{array}{l}\text { Natural Resources and Environmental } \\
\text { Science }\end{array}$ \\
\hline 10 & Intermediate & Doctoral student & Sociology \\
\hline 11 & Beginner & Senior & Pharmacy \\
\hline 12 & Experienced & Doctoral student & History-early modern Europe
\end{tabular}

tasks. Particularly, the information retrieval tasks (except for task 11) were designed to simulate the usage pattern that users tended to use certain parts of an e-book to find specific information but not read e-books from beginning to end. The tasks were created in a broad range of subject areas, but they were not related to the disciplinary backgrounds of participants. The e-book platforms involved in the information retrieval tasks are listed in the square brackets after the task instructions.

Response measures of the user tests included: (1) time to complete each test task; (2) number of times errors occurred for each task; (3) number of times help was needed for each task; (4) numbers of positive and negative comments from participants during each task; and (5) participants' responses to the posttest survey regarding their experience of the tasks. We also observed and took notes of how participants search, select, and read information from e-books.

At the beginning of the test, participants read and signed a consent form and were given a brief introduction about the purpose and procedures of the test. As a warmup, they were asked to provide their own definition of e-books and talk about the pros and cons of e-books from their experience. Participants then completed the test tasks listed in table 3 . They were encouraged to voice their expectations, difficulties, and general comments about the search process and e-books. A researcher sat next to participants, answered questions (providing prompts only when participants were stuck), and made observation notes about participant behavior. At the end of test tasks, participants completed a posttest survey regarding their overall experience of the test tasks. The open questions in the survey covered three areas: (1) participants' perception of e-books as a library resource and their comparisons of e-books with print books; (2) participants' search experience with e-books; and (3) the usability of e-book features. The postest survey allowed participants to reflect on the test tasks and give more feedback on their experiences with e-books without any distractions. Each user test session, including the test tasks and posttest survey, lasted approximately one hour. 


\begin{tabular}{|l|l|}
\hline \multicolumn{2}{|c|}{ Tasks for the User Tests } \\
\hline Task Type & Task Instruction \\
\hline $\begin{array}{l}\text { Searching for } \\
\text { e-books on general } \\
\text { subjects }\end{array}$ & $\begin{array}{l}\text { Use the library website to find one relevant e-book on the following } \\
\text { topics: } \\
\text { 1. iMovie } \\
\text { 2. Identity Design } \\
\text { 3. Marketing } \\
\text { 4. The Moon } \\
\text { 5. Greek Gods }\end{array}$ \\
\hline $\begin{array}{l}\text { Finding pieces } \\
\text { of information in } \\
\text { specific e-books }\end{array}$ & $\begin{array}{l}\text { Locate and open the following e-books and if possible, conduct the } \\
\text { following four actions: copy the answer; highlight the answer; add a } \\
\text { note next to the answer; and download the answer page(s). }\end{array}$ \\
\hline 6. & $\begin{array}{l}\text { In Pogue's iMovie'11 \& iDVD: The Missing Manual, find the } \\
\text { keyboard shortcut to showing/hiding the photos pane in iMovie. } \\
\text { [ProQuest Safari Books Online] }\end{array}$ \\
\hline 7. & $\begin{array}{l}\text { In White's (2008) book on neuroscience, find the definition of } \\
\text { Ideational Apraxia. [EBSCOhost] }\end{array}$ \\
\hline 8. & $\begin{array}{l}\text { In Norris's book Electoral Engineering: Voting Rules and Political } \\
\text { Behavior, find a table that lists the ideal functions of political } \\
\text { institutions. [ProQuest Ebrary] }\end{array}$ \\
\hline 11. & $\begin{array}{l}\text { In Bremmer's (2010) book about ancient Greece, find an aerial } \\
\text { view image of Olympia, the sanctuary in honor of Zeus. [ProQuest } \\
\text { Ebrary] }\end{array}$ \\
\hline $\begin{array}{l}\text { In Sarkar and Sarkar (2011) book Corporate Governance in India, } \\
\text { fnd what the corporate governance system in India in 800 B.C. was. } \\
\text { [ProQuest EBL] }\end{array}$ \\
$\begin{array}{l}\text { Find and open the book Landscape, Natural Beauty and the Arts } \\
\text { (Kemal, 1993) and tell us what it is about? [ACLS Humanities } \\
\text { E-Book] }\end{array}$ \\
$\begin{array}{l}\text { In Geismar's (2011) book Identify Basic Principles of Identity } \\
\text { Design in the Iconic Trademarks of Chermayeff \& Geismar, find the } \\
\text { meaning behind the Chase Manhattan Bank identity design in the } \\
\text { 1960s. [ProQuest EBL] }\end{array}$ \\
\hline 12.
\end{tabular}

\section{Results}

Performance Measures

As mentioned, the task performance measures included task completion time, number of errors, and help requests from participants, as well as their positive and negative comments.

The descriptive statistics for the task completion times are shown in table 5. Note that task 11 ("find and open the book Landscape, Natural Beauty and the Arts [Kemal, 1993] and tell us what it is about") did not ask participants to find or read a particular piece of information. In the test, most participants chose to skim the introduction and first several pages of the e-book before providing their answers. Therefore, task 11 had shorter average completion time compared to other information retrieval tasks.

There are a number of causes for errors in the search tasks. Beginner users had difficulty in identifying (such as clicking on print books instead of e-books) and limiting 
TABLE 5

Descriptive Statistics for Completion Time Count in Minutes for Each Task

\begin{tabular}{|c|c|c|c|c|c|}
\hline Task Type & Task & Min. & Max. & Mean & SD \\
\hline \multirow{5}{*}{$\begin{array}{l}\text { Searching } \\
\text { for e-books } \\
\text { on general } \\
\text { subjects }\end{array}$} & iMovie & 1.09 & 4.34 & 2.36 & 0.99 \\
\hline & Identity Design & 0.95 & 3.22 & 2.13 & 0.72 \\
\hline & Marketing & 1.09 & 5.1 & 2.44 & 1.14 \\
\hline & The Moon & 0.68 & 5.08 & 1.68 & 1.2 \\
\hline & Greek Gods & 0.42 & 3.53 & 1.33 & 0.84 \\
\hline \multirow{7}{*}{$\begin{array}{l}\text { Finding pieces } \\
\text { of information } \\
\text { in specific } \\
\text { e-books (see } \\
\text { Table } 2 \text { for } \\
\text { detailed task } \\
\text { instructions) }\end{array}$} & Find the keyboard shortcut & 2.79 & 7.23 & 4.71 & 1.5 \\
\hline & Find the definition & 3.27 & 6.2 & 4.57 & 0.98 \\
\hline & Find a table & 3.6 & 8.08 & 5.21 & 1.5 \\
\hline & $\begin{array}{l}\text { Find an aerial view image of } \\
\text { Olympia }\end{array}$ & 1.81 & 8.85 & 4.92 & 2.09 \\
\hline & $\begin{array}{l}\text { Find corporate governance system } \\
\text { in India in } 800 \text { B.C. }\end{array}$ & 2.74 & 7.74 & 4.39 & 1.53 \\
\hline & $\begin{array}{l}\text { Find and tell what the e-book is } \\
\text { about }\end{array}$ & 1.32 & 3.43 & 2.23 & 0.69 \\
\hline & $\begin{array}{l}\text { Find the meaning behind the Chase } \\
\text { Manhattan Bank identity design }\end{array}$ & 3.42 & 7.03 & 4.65 & 1.02 \\
\hline
\end{tabular}

the format (material type) of search results, which resulted in choosing articles or print books instead of e-books. The discovery tool (Primo) does not have a dedicated facet for e-books; instead, participants had to use a combination of "Online Access" and "Books" facets to limit search results to e-books. While the "Online Access" is obvious in the list of facets of Primo, beginners were not familiar with the fact that the "Books" facet is inside the "Material Type" group. This lack of direct facet for e-books also resulted in beginners spending time visually identifying e-books from the search results without applying any facet.

The help requests from participants during the test were mostly about: (1) understanding the general subjects to be searched (for instance, "Does 'the moon' mean the earth's satellite?"); (2) checking to see if a search result is relevant to the subject being searched (for example, "I think this is a marketing textbook. It is online. So it should be an e-book about marketing, right?"); and (3) identification of e-books (that is, the e-book format) from the search results (for instance, "I am not sure if this item is an ebook. Its label says 'Online access available. The library also has physical copies.'”). For the first two types of help requests, the researcher clarified the meaning of the general subjects, helped participants understand the information retrieval task instructions, and checked to see if a search result is relevant. Regarding the third type of help request, the researcher did not give straight answers but instead provided subtle guidance to encourage the participant to explore, such as: "Does the interface show more information about this item? What can you click to find out?" As mentioned, the researcher provided explicit help only when the participant attempted all the options known to him/her without success.

Positive comments from participants during the tasks covered e-book features like downloading chapters or the whole e-book for offline reading, e-books available in PDF format not requiring additional software, and relevance indication of search results within e-books (such as ProQuest Ebrary). 
Negative comments regarding the discovery tool include no direct e-book facet, other formats (such as journals, articles, and book reviews) appearing in book and media search results, and too many search results for general subject searches. Participants also complained about e-book interfaces and features, such as chapter headings not available, unable to click from table of contents and index to different book sections, limited e-book download options, limited search within e-book function, and confusing copy text functions.

\section{Searching for E-Books}

Most participants selected the "Books \& Media" tab on the Purdue Libraries homepage (see figure 6) to begin their searches. They simply used the subjects (topics) given to them as the query keywords without reformulating the queries. A few participants used the Advanced Search interface for some searches, searching the keywords in Titles and selecting the Material Type as Books.

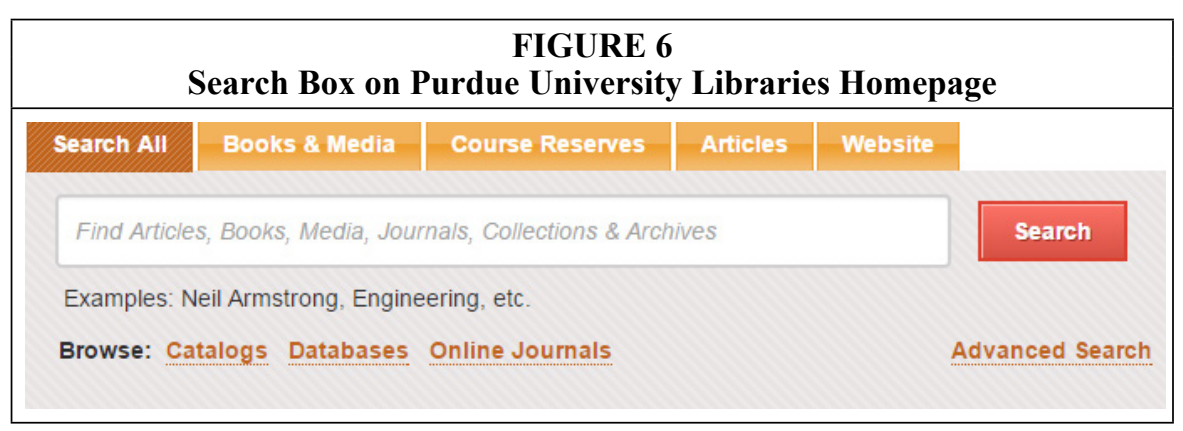

On the search results page (see figure 7), most participants browsed the first page of search results and selected an e-book based on its title. Browsing search results beyond the first page was rare. A few participants first selected a print book, but most participants noticed the difference between an e-book and a print book ("Online access available" versus "Print Available" as the status). The use of the "Details" tab under each search result was rare; participants tended to click on the title and view the e-book overview page to see if the e-book was relevant. Related to this, the "Details" tab in Primo usually shows only the catalog information such as Title, Author, Subjects, and Publisher, but not other useful information like book summary and table of contents. Although the general topic searches generated large numbers of search results, the majority of participants did not fully use the facets (see figure 7) to refine search results. The most used facets by participants were "Online Access" and "Book" in "Material Type."

Most search sessions were brief, with only a few actions on the search results page, probably because there was no detailed information for participants to assess the relevancy of each result. Participants had to open the e-book overview page from the source (that is, the e-book platform) to examine more detailed information such as book summary and table of contents.

\section{Finding Information in E-Books}

The difference of e-book experience significantly affected how participants completed the test tasks. Beginners conducted more searches within e-book than intermediate and expert users, while expert users relied more on the index, list of figures, list of tables, and table of contents before using the search within e-book function. For example, when looking for the definition of "Ideational Apraxia," expert users knew to search 


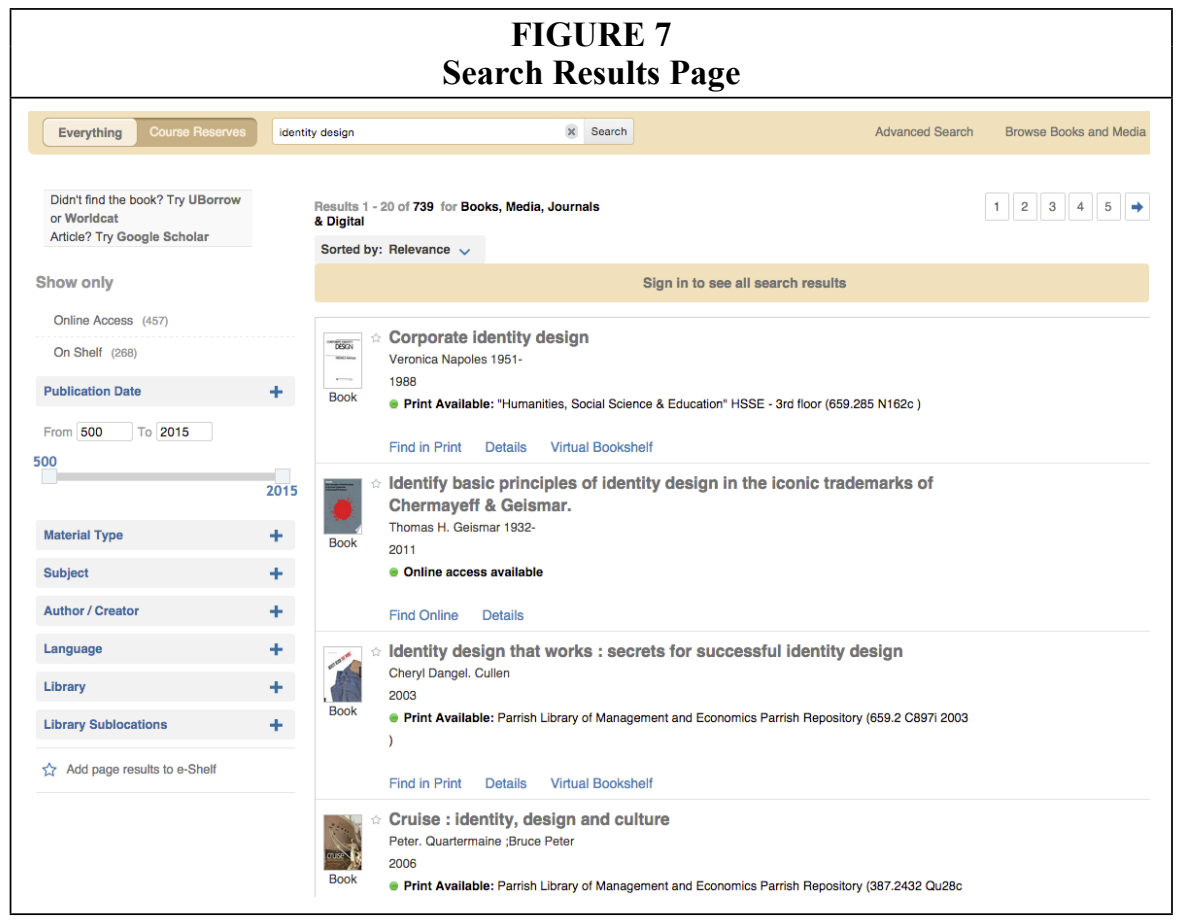

for the term under both " $\mathrm{I}$ " and " $\mathrm{A}$ " in the index, whereas beginners showed a lack of understanding of the index and list of figures and tables.

Beginners also had more difficulty understanding the search results in e-books than expert users. We noticed that the search within e-book function is relatively limited and far from the common web search experience. Beginners tended to type the exact phrase from the task instruction as the search query. But the search function matches any single keyword of the query in the book (not joining keywords or doing exact phrase search), which could generate a long list of results. Some e-books (such as EBSCOhost) do not highlight the keywords in the search results, making it difficult for participants to visually search for the matches. With more experience, expert users were able to develop better and unique search queries that resulted in fewer search results.

Some e-books have features that are different from common interaction paradigms, and participants across experience levels had difficulties understanding those features. For example, the e-brary e-book platform has a special copy button for copying text (see figure 8), but it does not have a tooltip to explain its function. After selecting the text, most participants chose to right-click and select the copy function in the quick menu, or pressed Ctrl $+\mathrm{C}$ keys. But the correct action is to click on the copy button and then press $\mathrm{Ctrl}+\mathrm{C}$ to copy the selected text in the dialog (see figure 9).

\begin{tabular}{|c|c|}
\hline \multicolumn{2}{|c|}{$\begin{array}{c}\text { FIGURE 8 } \\
\text { The Copy Button for Copying Text in Ebrary e-books }\end{array}$} \\
\hline 면 $\leq \square$ & Introduction \\
\hline $\begin{array}{l}\text { Elections are } n \\
\text { any means, but } \\
\text { about the appr }\end{array}$ & $\begin{array}{l}\text { differ sharply } \\
\text { at minimum, }\end{array}$ \\
\hline
\end{tabular}




\section{FIGURE 9}

The Copy Dialog after Clicking on the Copy Button in Ebrary e-books

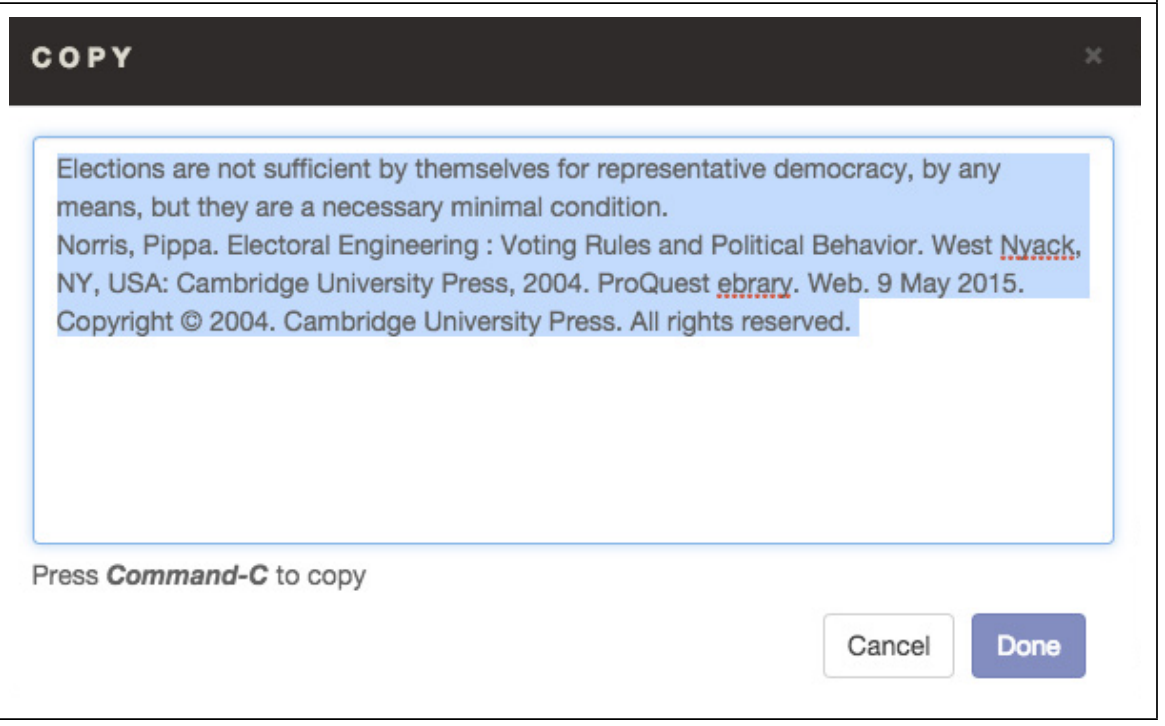

As another example, the EBL e-book platform shows pages in image form by default, which does not support direct text selection. To copy text from the e-book, users need to switch to the PDF display by clicking on the "COPY" or "PDF" button (see figure 10). The majority of participants spent some time figuring out this feature.

\begin{tabular}{|l}
\hline \multicolumn{2}{c|}{ FIGURE 10} \\
The COPY and PDF Buttons for Copying Text in EBL e-books
\end{tabular}

Beginners had more expectations of interacting with an e-book from their general web experiences than users with more e-book experience. Beginners tried to click on the page numbers in the table of contents (see figure 11; e-brary e-books) to go to a particular page. They wanted to scroll up and down pages, which may not be supported in some e-books (such as EBSCOhost). Some beginners tried to use the Ctrl + F shortcut to search for words on an e-book page, which again may not be supported.

\section{Posttest Responses}

A majority of participants thought finding e-books in the discovery tool is "somewhat difficult" (33\%) or "neutral" (33\%). The difficulty of e-book searches depends on the 


\begin{tabular}{|lr|}
\hline \multicolumn{1}{|c|}{ FIGURE 11 } \\
\hline \multicolumn{2}{|c|}{ The Table of Contents Page in Ebrary e-books } \\
\hline $\begin{array}{l}\text { List of Tables and Figures } \\
\text { Preface }\end{array}$ \\
PART I INTRODU vi \\
I Do Rules Matter? Structure versus Culture \\
2 Classifying Electoral Systems \\
3 Evaluating Electoral Systems & 3 \\
PART II THE CONSEQUENCES FOR VOTING BEHAVIOR & 39 \\
4 Party Systems & 66 \\
5 Social Cleavages & $8 \mathrm{I}$ \\
\hline
\end{tabular}

subject matter being searched, as the library's e-book collections vary for different subject areas. Ten of the 12 participants reported they used facets to refine search results.

Participant rated distinguishing between print books and e-books as "very easy" (17\%), "easy" (33\%), and "somewhat easy" (42\%), despite some difficulties shown in performance measures and our observations. The majority of participants $(58 \%)$ were neutral on whether it was easy for them to identify if an e-book would be helpful. Two participants rated "somewhat easy," two rated "easy," while one participant rated "difficult."

Participants' responses to the ease of reading e-books ranged from "somewhat difficult" (17\%), "neutral" (17\%), "somewhat easy" (33\%), to "easy" (33\%), indicating a wide range of individual differences. Some participants mentioned the discomfort of looking at the computer screen for long periods of time, while a few others said they were used to reading e-books on screens. The e-book interface and format could affect participants' ratings, as two participants mentioned the difficulty of zooming in or out in e-books when texts are small, as well as the difficult navigation within some e-books.

In line with previous researches on e-book reading, all participants reported doing more skimming, less thorough reading with e-books than print books. One participant stated the possible reasons for skimming e-books as, "feeling the book is very important" and "my eyes get quickly tired when I spend too much time reading on a screen." Another participant reported less highlighting and annotation in e-books than print books. These two comments indicate important limitations of current e-books: ergonomics of the screen display and limited interactive features for reading.

Participants are concerned about inconsistent print and download restrictions across e-book platforms. As of January 2016 at Purdue University, EBSCOhost e-books can be downloaded and read offline for up to seven days, and users can download up to 60 pages of an e-book. ProQuest Ebrary allows offline use of e-books for up to 14 days, and an individual chapter downloaded from an e-book does not expire. ProQuest Ebrary also has quotas for copying and printing pages as percentages of the book length. ProQuest EBL allows offline reading through Adobe Digital Editions, and users can print up to 20 percent and copy up to 5 percent of any e-book's total content. It is unlikely that users will understand these different restrictions when they are using e-books for their study and research. As a result, participants' ratings of the download and print features are mixed: two participants rated "very easy," five rated "easy," three rated "neutral," and two rated "somewhat difficult." Participants mentioned the difficulty of figuring out how to download or print a specific page or page range. One participant mentioned the use of print-screen button when there were limitations on downloading or printing. 
Participants complained that not all books are available in e-book format. One particular example from a participant is that the library removed a print book that he frequently needed but did not replace the print book with an equivalent e-book. Some e-book interfaces have potential accessibility issues. For example, ProQuest EBL by default shows e-book pages as images. To use a screen reader to read the text, users may have to manually switch the image view to PDF view on the interface.

Overall, there were concerns of inconsistent e-book layout and interface features from participants. Some e-book platforms have more advanced features and fewer restrictions than others. Participants had not only different task performances with the e-book platforms, but also different impressions of overall usability. We noticed that more experienced participants could quickly adapt to different e-book interfaces, while beginning users took a longer time to adjust to the differences.

\section{Discussion}

The analysis of usage data confirmed previous findings that academic e-books are mainly used as online references to extract information. The majority of reading sessions were no longer than 30 minutes, and long, thorough readings of a high number of pages or the entire e-book was rare. From the visualizations (see figures 4 and 5), a significant percentage of reading sessions involved just the beginning pages of e-books, suggesting that users were browsing or skimming the e-books to see if their content was relevant. Another significant pattern was the reading of certain page ranges, book sections, or chapters. This selective reading pattern showed that users considered some e-books to be collections of individual articles, and they were only interested in relevant chapters for their research needs.

The user tests showed that users' experience levels mediated their ability to search for information and navigate within e-books, as well as their awareness of different e-book features. Beginning users tended to rely on the search function when looking for specific information in e-books, while experienced users were more aware of the table of contents, list of tables and figures, and index. E-books in the user tests did not match the general web interaction paradigms. Inexperienced participants expected that all chapter titles, keywords, indexed terms, and page numbers would be hyperlinked, which was not consistently implemented across different e-book platforms. Besides being unfamiliar (unlike web search interface), the cross-platform inconsistencies may increase the learning curve for beginning users.

Furthermore, we observed that the inconsistent e-book features of search, navigation, and essential reading functions (copy, highlight, download, print, and notes) contributed to the disconnection between print and e-book user experience. Mismatches between user expectations and e-book features were a major source of usability concerns for participants. Users viewed the inconsistent limits on e-book download and print as a significant obstacle for them to effectively use e-books for their research. More important, the current e-book interface lacks support for effective navigation and information retrieval (for example, multiple-page view and search across multiple e-books) that is critical for nonlinear reading of scholarly publications. The full-text search function in e-books was not on par with the general web search experience. The table of contents, list of tables and figures, and index in some e-books were simple replications of the print books and did not support cross-references.

Academic reading is an active process of sense-making and knowledge development. To better support this dynamic process and different reading patterns, e-books should have a standard set of reading tools and features and, above all, offer a consistent user experience across different e-books. Given the impact of e-book platforms on user experience with e-book reading and their performance of the information-seeking 
TABLE 6

Summary of Preliminary Design Recommendations for eBook Interface

\begin{tabular}{|c|c|c|c|}
\hline $\begin{array}{l}\text { User Erperience } \\
\text { Phrase }\end{array}$ & $\begin{array}{l}\text { General Design } \\
\text { Recommendation }\end{array}$ & $\begin{array}{l}\text { User Behavior } \\
\text { Evidence }\end{array}$ & $\begin{array}{l}\text { Notes for Library } \\
\text { Instructions }\end{array}$ \\
\hline \multirow[t]{2}{*}{ Discovery } & $\begin{array}{l}\text { Discovery tools } \\
\text { need to have a direct } \\
\text { 'e-book' facet or } \\
\text { search option. }\end{array}$ & $\begin{array}{l}\text { It was difficult for } \\
\text { inexperienced users } \\
\text { to understand the } \\
\text { combination of } \\
\text { 'Online Access' and } \\
\text { 'Books' facets for } \\
\text { panowing down } \\
\text { sench results to } \\
\text { only e-books. }\end{array}$ & $\begin{array}{l}\text { Provide guides for } \\
\text { users to understand } \\
\text { the relevant facets } \\
\text { for filtering e-books } \\
\text { seurch results and how } \\
\text { to use those facets. }\end{array}$ \\
\hline & $\begin{array}{l}\text { Discovery too:s } \\
\text { need to display more } \\
\text { detailed information } \\
\text { (e.g., table of } \\
\text { contents and content } \\
\text { summary) about } \\
\text { e-books in addition } \\
\text { to title, author, and } \\
\text { publication year. }\end{array}$ & $\begin{array}{l}\text { From user tests, } \\
\text { participants spent a } \\
\text { considerable amount } \\
\text { of time exannining } \\
\text { book information } \\
\text { pages to see if an } \\
\text { e-book is relevant. }\end{array}$ & \\
\hline \multirow[t]{2}{*}{ Usage } & $\begin{array}{l}\text { Full text search } \\
\text { function in e-books } \\
\text { needs to support } \\
\text { pluase search beyond } \\
\text { simple keyword } \\
\text { match and better } \\
\text { relevancy ranking } \\
\text { of senrch results. } \\
\text { The experience of } \\
\text { searching within } \\
\text { e-books should be } \\
\text { similar to the general } \\
\text { web search. }\end{array}$ & $\begin{array}{l}\text { From user tests, } \\
\text { participants were } \\
\text { confused by the } \\
\text { large mumber of } \\
\text { results after typing } \\
\text { multiple search } \\
\text { keywords. } \\
\text { Some e-book } \\
\text { platforms do not } \\
\text { rank search results } \\
\text { by relevancy. }\end{array}$ & $\begin{array}{l}\text { Provide users } \\
\text { with accurate help } \\
\text { information about } \\
\text { the search function } \\
\text { in e-books, including } \\
\text { seurch exnmples and } \\
\text { its linitations. } \\
\text { Provide trainings on } \\
\text { how to effectively use } \\
\text { traditional inding aids } \\
\text { in both e-books and } \\
\text { print books (table of } \\
\text { couteats, index, list } \\
\text { of figures and tables, } \\
\text { bibliography, etc.). }\end{array}$ \\
\hline & $\begin{array}{l}\text { Navigation functions } \\
\text { such as table of } \\
\text { contents, list of } \\
\text { tables and figures, } \\
\text { and index should be } \\
\text { consistently designed } \\
\text { across e-books. }\end{array}$ & $\begin{array}{l}\text { The user tests } \\
\text { showed a unumber } \\
\text { of usability } \\
\text { issues restilted } \\
\text { from interface } \\
\text { inconsistency. }\end{array}$ & $\begin{array}{l}\text { Help users identify the } \\
\text { vavigation functions } \\
\text { in different e-book } \\
\text { interfaces. } \\
\text { Teach users how to } \\
\text { effectively use the } \\
\text { navigation tools or } \\
\text { finding aids in both } \\
\text { print books and } \\
\text { e-books. }\end{array}$ \\
\hline
\end{tabular}




\begin{tabular}{|c|c|c|c|}
\hline \multicolumn{4}{|c|}{$\begin{array}{c}\text { TABLE } 6 \\
\text { Summary of Preliminary Design Recommendations for eBools Interface }\end{array}$} \\
\hline $\begin{array}{l}\text { User Erperience } \\
\text { Phrase }\end{array}$ & $\begin{array}{l}\text { General Design } \\
\text { Recommendation }\end{array}$ & $\begin{array}{l}\text { User Behavior } \\
\text { Evidence }\end{array}$ & $\begin{array}{l}\text { Notes for Library } \\
\text { Instructions }\end{array}$ \\
\hline \multirow[t]{3}{*}{ Usage } & $\begin{array}{l}\text { The pagination of } \\
\text { e-books should match } \\
\text { with print books. }\end{array}$ & $\begin{array}{l}\text { In the user tests, } \\
\text { participants reported } \\
\text { mismatch of pages } \\
\text { numbers between } \\
\text { the e-book pages } \\
\text { and pagivation } \\
\text { interface. }\end{array}$ & $\begin{array}{l}\text { Help users use the } \\
\text { comect page numbers } \\
\text { (usually printed on the } \\
\text { actual e-book puges, } \\
\text { not from the e-book. } \\
\text { interface). }\end{array}$ \\
\hline & $\begin{array}{l}\text { E-books should } \\
\text { support cross- } \\
\text { refereace among } \\
\text { table of contents, list } \\
\text { of tables and figures, } \\
\text { and indes. }\end{array}$ & $\begin{array}{l}\text { In the user tests, } \\
\text { participants } \\
\text { had enrors and } \\
\text { negative comments } \\
\text { about inefficient } \\
\text { pavigation in } \\
\text { e-books. } \\
\text { User expected the } \\
\text { table of contents, list } \\
\text { of tables and figures, } \\
\text { and index to be } \\
\text { cross-referenced in } \\
\text { e-books. }\end{array}$ & $\begin{array}{l}\text { Provide necessary } \\
\text { information for users } \\
\text { to tuderstnud the lack } \\
\text { of cross-references } \\
\text { in current e-books. } \\
\text { Direct users to utilize } \\
\text { the existing vavigation } \\
\text { fuctions. }\end{array}$ \\
\hline & $\begin{array}{l}\text { E-books should } \\
\text { have common } \\
\text { and consistent } \\
\text { features for reading. } \\
\text { including copy. } \\
\text { highlight, annotation, } \\
\text { bookmark, print, } \\
\text { and downlond across } \\
\text { platforms. Limits } \\
\text { of these features } \\
\text { due to copyright } \\
\text { reasons should not } \\
\text { significantly affect } \\
\text { users" ability to } \\
\text { effectively retrieve } \\
\text { information from } \\
\text { e-books. }\end{array}$ & $\begin{array}{l}\text { The user tests } \\
\text { identifed } \\
\text { inconsistent feances } \\
\text { and limits on } \\
\text { download and print } \\
\text { of e-books, which } \\
\text { are possible causes } \\
\text { of usability concerns } \\
\text { from participants, } \\
\text { lower awareness of } \\
\text { features, and slort } \\
\text { reading sessions in } \\
\text { log acalysis results. } \\
\text { Participants in user } \\
\text { tests emplasized the } \\
\text { importance of these } \\
\text { features for students } \\
\text { to effectively } \\
\text { process scholarly } \\
\text { information in } \\
\text { e-books. }\end{array}$ & $\begin{array}{l}\text { Provide necessary } \\
\text { information for users } \\
\text { to understand the } \\
\text { limitations in current } \\
\text { e-books. Provide } \\
\text { alteruative solutions } \\
\text { when possible. }\end{array}$ \\
\hline
\end{tabular}




\begin{tabular}{|c|c|c|c|}
\hline \multicolumn{4}{|c|}{$\begin{array}{c}\text { TABLE } 6 \\
\text { Summary of Preliminary Design Recommendations for eBook Interface }\end{array}$} \\
\hline $\begin{array}{l}\text { User Erperience } \\
\text { Phrase }\end{array}$ & $\begin{array}{l}\text { General Design } \\
\text { Recommendation }\end{array}$ & $\begin{array}{l}\text { User Behavior } \\
\text { Evidence }\end{array}$ & $\begin{array}{l}\text { Notes for Library } \\
\text { Instructions }\end{array}$ \\
\hline \multirow[t]{3}{*}{ Usage } & $\begin{array}{l}\text { E-book content, } \\
\text { particularly figures } \\
\text { and tables, peeds } \\
\text { to be designed for } \\
\text { reading on digital } \\
\text { devices. }\end{array}$ & $\begin{array}{l}\text { From our } \\
\text { observation, wide } \\
\text { tables in e-books } \\
\text { were not rotated for } \\
\text { screen reading. } \\
\text { It was rare to see } \\
\text { interactive figures } \\
\text { or other medin in } \\
\text { e-books. Hyperlinks } \\
\text { in the text were not } \\
\text { always clickable. }\end{array}$ & $\begin{array}{l}\text { When possible, } \\
\text { provide users with } \\
\text { alterative solutions } \\
\text { (e.g., priating the page } \\
\text { with wide tables or } \\
\text { figures). }\end{array}$ \\
\hline & $\begin{array}{l}\text { E-books should start } \\
\text { to support devices } \\
\text { that use e-ink } \\
\text { technology to recuce } \\
\text { eye strain of users. }\end{array}$ & $\begin{array}{l}\text { In the user tests, } \\
\text { participants stated } \\
\text { that prolonged } \\
\text { screen reading leads } \\
\text { to discomfort of } \\
\text { their eyes. } \\
\text { E-book usage } \\
\text { data showed short } \\
\text { reacing times (no } \\
\text { longer than } 30 \\
\text { minutes) for the } \\
\text { majority of sessions. }\end{array}$ & \\
\hline & $\begin{array}{l}\text { E-books need to } \\
\text { have fexible display } \\
\text { and navigation } \\
\text { mechanisms to } \\
\text { support quick flipping } \\
\text { and skimming pages } \\
\text { that are common in } \\
\text { academic reading. }\end{array}$ & $\begin{array}{l}\text { In user tests, we } \\
\text { observed the } \\
\text { ineficient single } \\
\text { page view for } \\
\text { finding specific } \\
\text { information in } \\
\text { e-books. }\end{array}$ & $\begin{array}{l}\text { Provide guidance on } \\
\text { how to effectively use } \\
\text { existing navigntion } \\
\text { features in e-books } \\
\text { for common use } \\
\text { cases (e g., locating a } \\
\text { specific chapter, how } \\
\text { to use index, how to } \\
\text { fud a specific figure, } \\
\text { etc). } \\
\text { When possible, } \\
\text { provide users with } \\
\text { alterative solutions } \\
\text { (e.g., priating or } \\
\text { downloading the } \\
\text { relevant pages and } \\
\text { reading the pages } \\
\text { offline). }\end{array}$ \\
\hline
\end{tabular}




\begin{tabular}{|c|c|c|c|}
\hline \multicolumn{4}{|c|}{$\begin{array}{c}\text { TABLE } 6 \\
\text { Summary of Preliminary Design Recommendations for eBook Interface }\end{array}$} \\
\hline $\begin{array}{l}\text { User Erperience } \\
\text { Phrase }\end{array}$ & $\begin{array}{l}\text { General Design } \\
\text { Recommendation }\end{array}$ & $\begin{array}{l}\text { User Behavior } \\
\text { Evidence }\end{array}$ & $\begin{array}{l}\text { Notes for Library } \\
\text { Instructions }\end{array}$ \\
\hline Usage & $\begin{array}{l}\text { B-books should be } \\
\text { in common formats } \\
\text { without the need of } \\
\text { special software or } \\
\text { reader. }\end{array}$ & $\begin{array}{l}\text { Participants in user } \\
\text { tests were confused } \\
\text { by the two display } \\
\text { modes (image } \\
\text { and PDB) in EBL } \\
\text { e-books. } \\
\text { We observed } \\
\text { that some e-book } \\
\text { platforms recuire } \\
\text { special sofware to } \\
\text { downioad e-books. }\end{array}$ & \\
\hline
\end{tabular}

tasks, we have developed a preliminary list of e-book interface design recommendations based on our data analyses and user tests results (see table 6). Along with the design recommendations, we have also included a set of notes for improving library instructions of e-book users.

\section{Conclusion}

In this study, we developed a structured, user-centered assessment methodology by integrating e-book usage analysis and empirical user tests. We have summarized the behavior patterns from our observations of the user tests and discussed how these behavior patterns may be indicative of potential interface design and usability issues of e-book platforms. In general, we observed that the design of e-book interface needs to address the disconnection of reading experience from print books and support effective navigation and information retrieval in e-books. These findings could be used to direct the design of e-book features and overall user interactions. E-books will inevitably be part of library users' information resources, and it is critical for libraries to continuously improve the user experience of e-books to support users' research and study needs.

One limitation of the study is that we did not measure participants' prior experience of using print books in their study or research. We assumed that, being at a major research university, participants should be familiar with print books such as textbooks. Thus it may be difficult to identify specific effects of print book experience on participants' task performance. From our observations of user testing, it is likely that experienced e-book users also had more experience of using print books than inexperienced e-book users. Another related limitation is that we did not collect participants' prior research experience, discipline backgrounds, or other demographic measures, although the testing tasks were designed to not depend on any discipline knowledge and cover a wide range of subject areas. Furthermore, we believed that overall experience with the library website and e-books could better classify participants for this study. Because e-books are an important part of the library's collection, we expected that the prior experiences measured in the screening questionnaire could indicate distinct performance patterns in the user test. The differences between experts and novice users that we discussed in the results supported our hypothesis. Finally, having a researcher next to the participant during the user test could affect the participant's behavior, although the benefit of close observation probably outweighs the negative influence. 


\section{Acknowledgements}

This work is supported by a 2015 Library Fellowship from the Electronic Resources and Libraries (ER\&L) and EBSCO. The views and opinions expressed are those of the authors and do not necessarily reflect the views of the ER\&L and EBSCO. 


\section{APPENDIX A. Screening Questionnaire for User Test Participants}

\section{Introduction}

Thank you for your interest in helping us understand the user experience of e-books in academic libraries. The goal for this study is to gather information about how people perceive and identify relevant e-books and use e-book readers available via the library website to read e-books and find information. We would like to improve the e-book experience for users, from searching to reading.

The 5-minute survey below will ask about your experience with e-books and the Purdue University Libraries website. We shall use this information to group participants by experience level and schedule an equal number of evaluation tests from each group. Potential participants will receive a link to a shared Google Calendar where you can schedule for the evaluation study.

It may be possible that the quota for your corresponding experience level group is full and you won't be recruited for the study. In this case, your screening questionnaire responses and e-mail address will be deleted as soon as we have determined that no additional participants are needed for the study.

Please accept the terms to continue to the survey or close the tab to cancel. Thank you.

\section{Survey Questions}

1. For each item below, please select one frequency that best matches your experience:

$\square \quad$ Experience with Purdue University Libraries website

$\square \quad$ Experience with finding books on library website

$\square \quad$ Experience with finding scholarly articles on library website

$\square \quad$ Experience with finding e-books on library website

$\square \quad$ Experience with reading e-books from library website

$\square \quad$ Experience with downloading and printing e-books from library website

$\square \quad$ Experience with e-book readers like Kindle

$\square \quad$ Experience with reading e-books in mobile phone or tablet

(The frequency options are: "Never," "A few times ever," "2-3 times a year," "Monthly," "Weekly," "2-3 times a week," and "Daily.")

2. How do you find (locate) e-books?

3. For what purpose do you read e-books?

4. How do you read e-books? (Select all options that apply)

I read from start to end

$\square \quad$ I read the first few pages

$\square \quad$ I skim-read chapter beginnings

$\square \quad$ I read the chapter/pages I am interested in

$\square \quad$ I search the e-book for what I need

$\square \quad$ Other

5. What features of e-books do you usually use? (Select all options that apply.)

$\begin{array}{cl}\square & \text { Search } \\ \square & \text { Table of Content } \\ \square & \text { Index } \\ \square & \text { Download } \\ \square & \text { Copy \& Paste } \\ \square & \text { Printing } \\ \square & \text { Notetaking } \\ \square & \text { Highlighting } \\ \square & \text { Bookmarks } \\ \square & \text { Other }\end{array}$

6. Please provide us with an e-mail address, so we can schedule an evaluation time: 


\section{APPENDIX B. Posttest Participant Survey}

\section{Demographics}

Your age:

Your gender: Male / Female

If you are a student, please indicate which year you are currently in:

Freshman

$\square \quad$ Sophomore

$\square \quad$ Junior

$\square \quad$ Senior

$\square \quad$ Master's Student

$\square \quad$ Doctoral Student

If you are a professional, please indicate your position title:

Your major or research field:

Based on your experience with the library website and the e-book readers, please answer the following questions about searching, e-books, e-book readers, and other:

\section{Searching}

How easy is it for you to find e-books via the library website? Please explain after the option you selected.

$\begin{array}{ll}\square & \text { Very Difficult } \\ \square & \text { Difficult } \\ \square & \text { Somewhat Difficult } \\ \square & \text { Neutral } \\ \square & \text { Somewhat Easy } \\ \square & \text { Easy } \\ \square & \text { Very Easy }\end{array}$

Do you find the information provided about the tasks sufficient and clear for you to identify what you are looking for? Why?

Do you use any filters to better find what you are looking for? If yes, which filters do you use when looking for e-books on the library website?

Is it easy for you to distinguish between print books and e-books? Please explain.

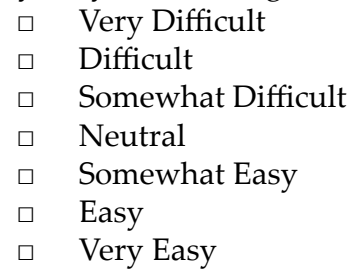

How easy is it for you to identify if an e-book will help you get your answer? Please explain.
$\square \quad$ Very Difficult
$\square \quad$ Difficult
$\square \quad$ Somewhat Difficult
Neutral 
$\square \quad$ Somewhat Easy

$\square \quad$ Easy

$\square \quad$ Very Easy

Do you find the e-book search results mostly relevant or irrelevant? Please give examples if you can.

How useful do you find e-books as a library resource? Please explain.

$\square \quad$ Not Useful at All

$\square \quad$ Mostly Not Useful

$\square \quad$ Neutral

$\square \quad$ Somewhat Useful

$\square \quad$ Very Useful

口 E-books

How easy is it for you to read e-books? Please explain.
$\square \quad$ Very Difficult
$\square \quad$ Difficult
$\square \quad$ Somewhat Difficult
$\square \quad$ Neutral
$\square \quad$ Somewhat Easy
$\square \quad$ Easy
$\square \quad$ Very Easy

How do you find e-books in comparison to traditional print books? Do you read ebooks differently from print books?

What would you say are the strengths of e-books over traditional print books?

What are the weaknesses of e-books in comparison to print books?

How easy is it for you to understand your current location/position in an e-book? Please explain.
$\square \quad$ Very Difficult
$\square \quad$ Difficult
Somewhat Difficult
$\square \quad$ Neutral
$\square \quad$ Somewhat Easy
$\square \quad$ Easy
$\square \quad$ Very Easy

\section{E-book Readers}

How easy is it for you to use the e-book readers? Please explain.
$\square \quad$ Very Difficult
$\square \quad$ Difficult
․ Somewhat Difficult
$\square \quad$ Neutral
$\square \quad$ Somewhat Easy
$\square \quad$ Easy
$\square \quad$ Very Easy 
How easy is it for you to find specific information in an e-book? Please explain.

$\begin{array}{cl}\square & \text { Very Difficult } \\ \square & \text { Difficult } \\ \square & \text { Somewhat Difficult } \\ \square & \text { Neutral } \\ \square & \text { Somewhat Easy } \\ \square & \text { Easy } \\ \square & \text { Very Easy }\end{array}$

How easy is it for you to download and print e-books from the readers? Please explain.

$\begin{array}{cl}\square & \text { Very Difficult } \\ \square & \text { Difficult } \\ \square & \text { Somewhat Difficult } \\ \square & \text { Neutral } \\ \square & \text { Somewhat Easy } \\ \square & \text { Easy } \\ \square & \text { Very Easy }\end{array}$

How important is it for you to be able to highlight, annotate, or take notes into the e-book? Please explain.

What other functionalities would you like to have on e-book readers?

\section{Other}

Do you have any other comments or suggestions about the e-book readers available on the library website?

How would you define an e-book after the tasks?

\section{Notes}

1. Rajendra Kumbhar, "E-Books: Review of Research and Writing during 2010: The Electronic Library: Vol 30, No 6," The Electronic Library 30, no. 6 (2012): 777-95.

2. Wendy Allen Shelburne, "E-Book Usage in an Academic Library: User Attitudes and Behaviors," Library Collections, Acquisitions, and Technical Services 33, no. 2/3 (Jan. 2009): 59-72. doi:10.1016/j.lcats.2009.04.002.

3. Sheila O'Hare and Andrew J.M. Smith, "The Customer Is Always Right? Resistance from College Students to E-Books as Textbooks," Kansas Library Association College and University Libraries Section Proceedings 2, no. 1 (Jan. 1, 2012): 35-41. doi:10.4148/culs.v2i0.1615.

4. Representative studies include Michael Heyd, "Three E-Book Aggregators for Medical Libraries: NetLibrary, Rittenhouse R2 Digital Library, and STAT!Ref," Journal of Electronic Resources in Medical Libraries 7, no. 1 (Mar. 2010): 13-41, doi:10.1080/15424060903585693; Jenny Pierce, "R2 Library: A Review," Journal of Electronic Resources in Medical Libraries 8, no. 4 (Oct. 2011): 430-40, doi:10.1080/15424065.2011.626358; Denise Shereff, "Electronic Books for Biomedical Information," Journal of Electronic Resources in Medical Libraries 7, no. 2 (June 7, 2010): 115-25, doi:10.1080/15424 065.2010.482903; Laura C. O'Neill, A Usability Study of E-Book Platforms (Chapel Hill: University of North Carolina at Chapel Hill, 2009).

5. Hamid R. Jamali, David Nicholas, Ian Rowlands, (2009) "Scholarly e-books: the views of 16,000 academics: Results from the JISC National E-Book Observatory", Aslib Proceedings, Vol. 61 Issue: 1 (33-47), doi: 10.1108/00012530910932276.

6. Jeff Staiger, "How E-Books Are Used: A Literature Review of the E-Book Studies Conducted from 2006 to 2011," Reference \& User Services Quarterly 51, no. 4 (2012): 355-65; Noorhidawati Abdullah and Forbes Gibb, "Students' Attitudes towards E-Books in a Scottish Higher Education Institute: Part 2: Analysis of E-Book Usage," Library Review 57, no. 9 (2008): 676-89.

7. Abdullah and Gibb, "Students' Attitudes Part 2." 


\section{Assessing the User Experience of E-Books in Academic Libraries 601}

8. Dana McKay, "A Jump to the Left (and Then a Step to the Right)," in Proceedings of the 23rd Australian Computer-Human Interaction Conference on-OzCHI '11, 202-10 (New York, New York, USA: ACM Press, 2011). doi:10.1145/2071536.2071569.

9. Michael Levine-Clark, "Electronic Book Usage: A Survey at the University of Denver," portal: Libraries and the Academy 6, no. 3 (2006): 285-99; Tina Chrzastowski, "Assessing the Value of Ebooks to Academic Libraries and Users," in Proceedings of the 9th Northumbria International Conference on Performance Measurement in Libraries and Information Services, 2011; Peter Hernon, Rosita Hopper, Michael R. Leach, Laura L. Saunders, and Jane Zhang, "E-Book Use by Students: Undergraduates in Economics, Literature, and Nursing," Journal of Academic Librarianship 33, no. 1 (Jan. 2007): 3-13, doi:10.1016/j.acalib.2006.08.005; Lorraine Estelle, Caren Milloy, Ian Rowlands, and Hazel Woodward, "Understanding How Students and Faculty REALLY Use E-Books: The UK National E-Books Observatory," in ElPub2009: 13th International Conference on Electronic Publishing, 2009.

10. Noorhidawati Abdullah and Forbes Gibb, "Students' Attitudes towards E-Books in a Scottish Higher Education Institute: Part 3: Search and Browse Tasks," Library Review 58, no. 1 (2009): 17-27.

11. Maria Brahme and Lizette Gabriel, "Are Students Keeping Up with the E-Book Evolution? Are E-Books Keeping Up with Students' Evolving Needs? Distance Students and E-Book Usage, A Survey," Journal of Library \& Information Services in Distance Learning 6, no. 3-4 (July 2012): 180-98, doi:10.1080/1533290X.2012.705109; Rosie Croft and Corey Davis, "E-Books Revisited: Surveying Student E-Book Usage in a Distributed Learning Academic Library 6 Years Later," Journal of Library Administration 50, no. 5-6 (Aug. 10, 2010): 543-69, doi:10.1080/01930826.2010.48 8600; Hernon, Hopper, Leach, Saunders, and Zhang, "E-Book Use by Students"; Paul Lam, Shun Leung Lam, John Lam, and Carmel McNaught, "Usability and Usefulness of eBooks on PPCs: How Students' Opinions Vary over Time," Australasian Journal of Educational Technology 25, no. 1 (2009): 30-44.

12. Dracine Hodges, Cyndi Preston, and Marsha Hamilton, "Resolving the Challenge of EBooks," Collection Management 35, no. 3 (July 2010): 196-200, doi:10.1080/01462679.2010.48696; William H. Walters, "E-Books in Academic Libraries: Challenges for Discovery and Access," Serials Review 39, no. 2 (2013): 97-104.

13. James A. Buczynski, "Library eBooks: Some Can't Find Them, Others Find Them and Don't Know What They Are," Internet Reference Services Quarterly 15, no. 1 (Feb. 26, 2010): 11-19, doi:10.1080/10875300903517089; Shelburne, "E-Book Usage"; Noorhidawati Abdullah and Forbes Gibb, "Students' Attitudes towards E-Books in a Scottish Higher Education Institute: Part 1," Library Review 57, no. 8 (2008): 593-605; Brahme and Gabriel, "Are Students Keeping Up?"

14. Levine-Clark, "Electronic Book Usage"; Staiger, "How E-Books Are Used."

15. Hernon, Hopper, Leach, Saunders, and Zhang, "E-Book Use by Students"; Levine-Clark, "Electronic Book Usage"; Shelburne, "E-Book Usage."

16. Muhammad Asim Qayyum, "Capturing the Online Academic Reading Process," Information Processing \& Management 44, no. 2 (Mar. 2008): 581-95. doi:10.1016/j.ipm.2007.05.005.

17. Tao Zhang and Xi Niu, "The User Experience of E-Books in Academic Libraries: Perception, Discovery, and Use," in E-Books in Academic Libraries: Stepping Up to the Challenge, eds. J. Nixon, S. Ward, and R. Freeman (West Lafayette, Ind.: Purdue University Press, 2015).

18. Buczynski, "Library eBooks"; Shelburne, "E-Book Usage."

19. Abdullah and Gibb, "Students' Attitudes Part 1."

20. Barbara L. Folb, Charles B. Wessel, and Leslie J. Czechowski, "Clinical and Academic Use of Electronic and Print Books: The Health Sciences Library System E-Book Study at the University of Pittsburgh," Journal of the Medical Library Association: JMLA 99, no. 3 (July 2011): 218-28, doi:10.3163/1536-5050.99.3.009; Staiger, "How E-Books Are Used."

21. Selinda Adelle Berg, Kristin Hoffmann, and Diane Dawson, "Not on the Same Page: Undergraduates' Information Retrieval in Electronic and Print Books," Journal of Academic Librarianship 36, no. 6 (Nov. 2010): 518-25. doi:10.1016/j.acalib.2010.08.008.

22. McKay, "A Jump to the Left." 